brother, Gil Liebenow, all of Illinois; and eight grandchildren.

Patrick O'Meara

N. Brian Winchester

Indiana University

John Daly

University of South Florida

\section{Donald O. Schoonmaker}

Donald O. Schoonmaker, 55, professor of politics at Wake Forest University, died May 20, 1993, after a five-month illness from complications related to treatment for leukemia.

Professor Schoonmaker was born in New York. He was a graduate of Wake Forest University (A.B. 1960) and Princeton University (M.A. 1962 and Ph.D. 1966).

He taught briefly at Pennsylvania State University (1963) and the University of Maryland, European Division in West Germany (1963-65). In 1965 , Dr. Schoonmaker joined the faculty of the department of politics at Wake Forest University where he spent the bulk of his professional career, becoming a professor in 1982 . He taught courses and conducted research in comparative politics with an emphasis on Germany and Western European governments. He had a special interest in films and literature as sources of insight into politics. His courses were popular and challenging, attracting many of the university's finest students for whom he served as a compassionate mentor and friend, as well as teacher.

Don was a member of several professional associations. He frequently presented scholarly papers at the American Political Science Association, the Council on European Studies, the German Studies Association and the Conference Group on German Politics. Recently he served as an officer in the latter, being chosen as president-elect for the 1993-94 academic year. His research was aided by several fellowships including awards from the Woodrow Wilson Foundation, the Fulbright Scholar program, the National Endowment for the Humanities, and the German Exchange Fellowship program.
Since the early 1980s, Professor Schoonmaker published articles and chapters in books on aspects of German electoral activities and political parties. Among these were items published in the Review of Politics, When Parties Fail (edited by K. Lawson and P. Merkl), and The New Germany: Unification and the Development of the New German Party System (edited by R. Dalton, 1993). His two books on German politics include German Politics (Heath, 1971) and Between Protest and Power: The Green Party in Germany (Westview, 1992) which was coauthored by Gene Frankland. He coedited and contributed to a volume, English Romanticism: Preludes and Postludes (Colleagues Press, 1993).

Don was a very active member of the university faculty and a conscientious citizen in his home community. He served on numerous civic boards and organizations. Among these were the Experiment in Self-Reliance, a local antipoverty agency; Common Cause, a public interest group; and the Afro-American Historical Society.

In March 1993, he was selected to receive the Wake Forest University Alumni Association's Faculty Prize for outstanding community service. Seen by many as a "conscience of the community," he was an eloquent and passionate spokesman for racial and social justice.

Professor Schoonmaker leaves his devoted wife Meyressa; a daughter and son-in-law, Kirsten Schoonmaker-Bryant and Darren Bryant, and a son Trevor Owen Schoonmaker. His premature and quick departure leaves a void in his university, his community, and his profession. He leaves a rich legacy and many happy memories.

Jack D. Fleer

Katy J. Harriger

Richard D. Sears

Wake Forest University

\section{William J. Siffin}

Bill Siffin's academic career began over fifty years ago as an Indiana University undergraduate, where he earned a B.S. in business administra- tion in 1943; it included an M.A. in public administration from the University of Minnesota and a Ph.D. from Harvard. By the mid-fifties Indiana had reclaimed Bill, who returned to Bloomington where he lived with his wife, Catherine Fox Siffin, and his three children, Mark, Louise, and Kelly, while serving Indiana University as an active faculty member for thirty-six years, and a still active emeritus for five more years.

Few faculty members were more cosmopolitan, more acquainted with and concerned about the realities of life in the international arena than Bill. His long-standing dedication to an understanding of international affairs and the development of institutional structures in developing countries grew from a solid base of knowledge drawn from the American administrative experience. His graduate work concentrated more on American than foreign phenomena, resulting in a dissertation (later published by the I.U. Press) on legislative councils in American states. Building on this foundation of close acquaintance with American public affairs, Bill became one of the central figures in an influential intellectual movement addressing issues of comparative administration, particularly the international and intercultural dimensions of public administration.

This movement, in which he was certainly one of the best known participants, transferred American administrative experience and lore to scores of developing countries around the world, affecting the thinking and practice of the scholars and officials in these countries who were and are trying to cope with almost insoluble problems. Perhaps just as important, it significantly affected the ideas of American scholars of public affairs, raising new questions about the models and postulates of American doctrine.

Bill Siffin's contributions to this debate began as early as the 1950s, when he edited and contributed to a volume entitled Toward the Comparative Study of Public Administration. With his colleague and longtime friend, Fred Riggs, Bill participated actively in the Indiana University Comparative Administration 
Group. One of the most intellectually exciting activities of its time, this group explored the transferability of administrative institutions from one nation and culture to another. Using the insights developed in his studies, Bill served as a chief participant in the Inter-University Research Program in Institution Building, involving scholars in a number of universities, and was active in the International Institute of Administrative Sciences, U.N. seminars on management, and the Eastern Regional (largely Asiatic) Organization for Public Administration.

He was never an ivory tower academic; he had more than an intellectual interest in public administration. During the 1950s he spent two years in Bangkok as one of the central participants in Indiana University's efforts to help the Thais deal with problems of public administration. In the sixties he lived in Honolulu for a year as a senior scholar at the EastWest Center. In the seventies, he was on leave from I.U. for two years to serve as director of the Office of Development Administration of the U.S. Agency for International Development, improving the quality of administration in many countries receiving - or hoping to receiveU.S. aid.

During the seventies and eighties, his work as director of Indiana University's International Development Institute and of the Program of Advanced Studies in Institutionbuilding and Technical Assistance Methodology placed him in the forefront of the continuing debate over issues of development administration and international technical assistance. He has been an advisor and consultant on management and administration for United Nations agencies, the Ford Foundation, the World Bank, and various individual foreign countries. In Thailand, where his close ties go back nearly forty years, he was awarded the rank of Commander in the Royal Order of the White Elephant by King Bhumipol.

In 1986, he received the first Fred Riggs Award from the Society of International Comparative Administration in honor of his contributions to the field, and a year later, won election to the National Academy of Public Administration. In
1991 he was the recipient of Indiana University's John W. Ryan Award for Distinguished Contribution to International Programs and Studies.

Throughout his career, Bill was an active and effective citizen of the academic communities of which he was a part. He was on the faculty of both the department of political science and the School of Public and Environmental Affairs; he was director of graduate studies for the department and a member of its executive committee, a member of the policy committee of the College of Arts and Sciences, and acting dean of international programs. For a number of years he represented Indiana University on the board of the Midwest Universities Consortium for International Activities. He was active in the American Society for Public Administration and the American Political Science Association-he was a member and chairman of the editorial board of PS.

For a dozen years before his death, Bill had health problems of increasing severity. He fully understood the seriousness of these problems, but would not admit or give in to them if he could avoid it, nor let them deter him from the things that he wanted to do. He continued to travel extensively, to consult, to write, to teach, with the same cheer and enthusiasm he had always had. It was completely characteristic of him that he was at his office, at his desk, doing some of the things that he wanted to do, on the last day of his life, in spite of his full acquaintance with his rapidly increasing physical frailty.

Eloquent, literate, amused, and brilliant, William J. Siffin brought energy, inspiration, charm, and perspective to a generation of colleagues, students, and friends. No one exposed to the Siffin wit and wisdom ever fully recovers, and each of us touched by his generous enthusiasm for knowledge and growth or zinged by his ferociously creative vocabulary cherishes the experience.

Byrum Carter

Alfred Diamant

York Willbern

Indiana University

\section{Aaron B. Wildavsky}

Aaron Wildavsky, age 63, died peacefully at his home in Oakland, California, of lung cancer on September 4,1993 . At the time of his death, he was Class of 1940 Professor of Political Science and Public Policy at the University of California at Berkeley, where he had taught since 1962. He was chairman of the political science department and founding dean of the Graduate School of Public Policy at Berkeley. From 1958-62 he taught at Oberlin College and he was briefly (in 1977) president of the Russell Sage Foundation. He held honorary degrees from Brooklyn College, his alma mater; Yale University, from which he had received his Ph.D.; and the University of Bologna, an honor conferred on the 900th anniversary of the university. He was president of the American Political Science Association in 1985-86, and was perhaps the most honored political scientist of his generation, at various times receiving prizes and awards named for Dwight Waldo, Charles E. Merriam, William Mosher, John Gaus, Harold Lasswell, Paul F. Lazarsfeld, and John Simon Guggenheim. His book, Politics of the Budgetary Process, was named by the American Society for Public Administration as the third most influential work in public administration in the last 50 years. He was a Fellow of the American Academy of Arts and Sciences, the National Academy of Public Administration, and the Center for Advanced Study in the Behavioral Sciences.

Wildavsky wielded an unusually prolific pen. He was author or coauthor of some 39 books (with more to come) and a great many articles and reviews, including important works on the budgetary process, policy analysis, political culture, foreign affairs, public administration, and comparative government. He wrote also on presidential elections and on the craft of political science. He taught assiduously and successfully, sending numerous Oberlin students on to graduate school, and sponsoring a large and devoted corps of Berkeley Ph.D.s.

The recitation of these accomplishments begins to suggest the pro- 